[Transaction ]

\title{
Exploratory Correlation Analysis among Age Identity, Proximity of Clothing to Self, and Self-Actualization for Older Persons in the United States
}

\author{
Young-A Lee \\ Dept. of Apparel, Educational Studies, \& Hospitality Management, Iowa State University \\ Received August 26, 2009; Revised (November 10, 2009; November 22, 2009); Accepted November 28, 2009

\section{미국 노년층의 의복의 자아 근접성, 나이 정체성, 자아실현 사이의 상호연관성 분석} \\ 이 영 아 $^{\dagger}$ \\ Dept. of Apparel, Educational Studies, \& Hospitality Management, Iowa State University \\ 접수일(2009년 8월 26일), 수정일(1차 : 2009년 11월 10일, 완료일 : 2009년 11월 22일), 게재확정일(2009년 11월 28일)
}

\begin{abstract}
This large-scale research project contributes to the theory development in the importance of clothing to the self and in the way that older persons might age successfully by fulfilling the need for self-actualization by incorporating a primary resource environment, such as clothing into their self-system. This paper presents one research objective from a lager project that explores the correlations among the Proximity of Clothing to Self (PCS), age identity (subjective or perceived age), and self-actualization (the highest level of human needs). A mail survey design was applied to this study. In November 2004, two questionnaires, Clothing: A Resource for Successful Aging? (to measure PCS, age identity, and demographic variables) and Personal Orientation Inventory (to measure self-actualization), were sent to 1,700 older persons in the U.S. and 195 completed usable questionnaires were returned (12\% response rate). This research discovered that the age identity of older persons did not relate with PCS except for those 85 years and over. There were negative correlations among subscales of PCS and self-actualization. This result can be interpreted as that an older person who has not met the highest level of needs yet, can use clothing as a facilitator or need satisfier to meet a higher level of Self-Actualization (SA). Correlation analyses also revealed that older persons in the age category of 75 to 84 years were different from those in the category of 65 to 74 years and 85 years and over. This result implies that older persons in this age category are undergoing more psychological transitions than those in other categories. Further research is necessary to explore the relationship of several SA subscales with various clothing variables such as clothing interest, clothing involvement, or clothing satisfaction.
\end{abstract}

Key words: Age identity, Older persons, Proximity of clothing to self, Self-Actualization; 의복의 자아 근접성, 노년층, 자아실현, 나이 정체성

Corresponding author

E-mail: ylee@iastate.edu

This work was supported by the Michigan Agricultural Experiment Station and Kappa Omicron Nu Honor Society for being a recipient of a Beatrice Paolucci Research Grant.

\section{Introduction}

In 2000, older persons 65 and over in the U.S. constituted approximately 12.4 percent of the total popu- 
lation (U.S. Bureau of the Census, 2005). The older population in 2030 is projected to be twice as large as in 2000 , growing from 35 million to 72 million and presenting nearly 20 percent of the total U.S. population at the latter date. Moreover, the first wave of the 76 million baby boomers born between 1946 and 1964 will approach traditional retirement age in 2010. By 2050, the number of centenarians in the U.S. may be as high as 4.2 million.

The aging process creates change in the lives of older persons (Rowe \& Kahn, 1998). They experience physiological, social, and psychological transitions that place new demands upon them. There are many physiological changes that accompany the aging process such as loss of skin elasticity, porous bone structure, wasting muscles, and so on. Adapting to changes in roles, loss of control in residency and reduction of social opportunities all can bring some isolation. In addition, retirement and limited social contacts due to death and disability of close family members or friends may cause some social isolation as well as psychological isolation. Because of these various major changes in their later lives, clothing may be seldom considered as an important part in their lives. However, clothing indeed goes far beyond protection, modesty, and decoration; it differentiates and identifies, communicates a great deal, and expresses self-image and personality. In addition, it buttresses self-esteem, projects regard for others, influences behavior, and proclaims status, taste, and aesthetic sensitivity. Further it can contribute to a sense of well-being and selfacceptance.

Older persons' lives are no longer restricted by their chronological age; rather than that their perceived age, age identity, is more important for their daily activities. Clothing is one human environmental resource and can be used to meet various levels of needs for older persons; however, still little is known about the meaning of clothing to themselves and the way to use clothing to meet older persons' various levels of needs. This research pays attention to this unexplored area so it can demonstrate the way that clothing can be a facilitator of their various daily activities to age successfully, especially with regard to role which the psychological aspects of successful aging plays in self-system.

\section{Research Purpose and Objective}

The purpose of a large research project was to contribute to theory development in the importance of clothing to the self and in the way that older persons might age successfully by fulfilling the need for selfactualization by incorporating a primary resource environment, i.e., clothing, into their self-system. Lee (2007) investigated only direct impacts of the PCS on overall self-actualization and of overall self-actualization on age identity. No relationship among each PCS subscale with overall self-actualization or each subscale of self-actualization or with age identity was examined in the structural model testing.

This paper explores correlations among proximity of clothing to self, age identity, and self-actualization to explain a few hypotheses that were rejected or had a reverse effect (i.e., negative rather than positive) of one variable on the other in Lee's study (2007). It is important to understand the relationships among clothing and these human-related variables for each individual's healthy daily living through his or her life span. The exploratory correlation analyses will be able to lead the development of more advanced directional analyses among these variables in future research.

\section{Literature Review and Theoretical Definitions of Research Concepts}

Due to various experiences of aging many older persons may suffer a loss of self-confidence and be deprived from self-actualization. Clothing can make the physiological changes less traumatic, and it can be one need satisfier which allows older persons to engage with life more actively. Clothing is an easily obtainable product that can be used as a tool in the adjustment to life changes. Pedersen (1989) recognized clothing as a need satisfier having biophysical, social, and psychological value for all people. This can allow older persons to continue feeling good about themselves and allows them to project a positive selfimage.

Proximity of Clothing to Self (PCS) is "the psy- 
chological closeness of clothing to the self" (Lee \& Sontag, 2007; Sontag \& Lee, 2004). Whereas clothing has been referred to as "the second skin" and "the visible self," people vary in their perceptions of clothing as an expression of the self and in the use of clothing in adaptive functioning for the self (Sontag $\&$ Schlater, 1982). The PCS construct has been found to be positively related to perceived quality of life (Sontag, 1978; Sontag \& Schlater, 1982), apparel involvement and shopping behavior (Vreeman, 1985), and chronological age and age identity (Lee, 2005; Lynn, 1990). However, PCS has been found to be negatively related to self-actualization of older persons (Lee, 2007); and the body image/body cathexis dimension of PCS was negatively related to physical appearance self-concept of adolescents (Lee, 1997). Correlation analysis between PCS and self-actualization in this study will provide some insight for the negative direct relationship of PCS to self-actualization.

Age identity, that is perceived age, has been seen as a way of helping to explain the individual's psychological age in various areas of research. Baum and Boxley (1983) argued that people are as old as they feel. Their argument challenges the belief that chronological age and age identity is homogeneous for all older people. Older persons do not necessarily have the same chronological and psychological age. Feeling younger than their age provides them with the incentive to act and look younger (Baum \& Boxley, 1983). Clothing can help them accomplish this goal. Perceiving themselves as younger than their chronological age may improve perceived well-being and self-esteem (Linn \& Hunter, 1979).

Self-actualization refers to the need for selffulfillment, namely, to the tendency for the person to become actualized in what he or she is potentially. This tendency might be phrased as the need to become more and more what one is, to become everything that one is capable of becoming (Maslow, 1970). Combs and Snygg (1959) also described the self-actualizing person as:

"... one who has achieved a high degree of need satisfaction. These are people who feel generally capable of coping with life. ... They see themselves in essentially positive ways and as a consequence are free and open to their experience, able to accept both themselves and others and to identify strongly with their fellow-men. ... Events seem to them to lie well within their own capabilities, and they feel capable of dealing with life effectively and efficiently" (pp. 239-240).

In clothing research, limited research (Creekmore, 1974; Pasnak \& Ayres, 1969) has been conducted to explore the relationships of clothing variables to the self-actualization need of older persons as well as other population.

In sum, previous research supports that an older person's chronological age has a positive relation to one's age identity. An older person who perceives oneself younger than one's chronological age has a high level of clothing importance and clothing interest (Chowdhary, 1988); further this person has higher self-confidence than a person who has higher age identity. This result may suggest that an older person who is highly fulfilled in one's life (i.e., self-actualized) perceives oneself younger than one's chronological age. When an older person ages, clothing importance and level of PCS also increases based on previous research (Chowdhary, 1988; Lynn, 1990). Clothing importance is also positively related to selfesteem (Chowdhary, 2000). An older person uses clothing to meet many other needs as well. Self-actualization, the higher level need, may be met by using clothing.

\section{Methods}

Mail survey design was applied in this study and followed the guidelines of Salant and Dillman's (1994) total design method throughout the data collection.

\section{Research Population and Sample Charac- teristics}

The population under this study was older persons, males and females age 65 and above who live in noninstitutional settings in the U.S. A national random sample list of 1,700 older persons living at home, stratified by sex, age 65 and over was purchased from Survey Sampling International (SSI) in Fair- 
field, Connecticut in November, 2004. The SSI population database was compiled from telephone directories, driver licenses, and other purchased lists. The number of men and women in the sample was proportional to the representation of the U.S. older population as reported in the 2000 Census of Population (U.S. Bureau of the Census, 2001): 43 percent male $\left(\mathrm{N}_{\mathrm{M}}=731\right)$ and 57 percent female $\left(\mathrm{N}_{\mathrm{F}}=969\right)$.

The 195 usable survey respondents were from 45 states among the 50 states in the U.S. The respondent's age range was from 65 to 94 years old having a mean age of 76. According to the U.S. Bureau of the Census (2005) population age classification, the respondents were grouped under the three different age categories: 65 to 74 years, 75 to 84 years, and 85 years and over. Among 195 respondents, about 46\%, $40 \%$, and $14 \%$ of the older persons were in the age categories of 65 to 74 years, 75 to 84 years, and 85 years and over, respectively. Eighty-five percent had an education level of high school completion and over. Median income range was from $\$ 20,000$ to $\$ 27,499$. Most respondents were white $(91 \%)$ and lived alone (49\%) or with a spouse (40\%). Over $80 \%$ of the respondents were retired; but among those, around $26 \%$ were involved in other activities such as another full-time or part-time job or volunteer work. Overall, the data from the respondents were consistent with the data of the U.S. older population in terms of the proportion by sex and age. However, the respondents were mostly White, had higher education, and were in higher income ranges compared with that of the U.S. older population. Although the data from the respondents were consistent with the data of the U.S. older population, it should not be overestimated to generalize the results of this research result because of having such a small number of survey respondents.

\section{Survey Instrument and Procedure}

Following a pretest of the questionnaires with 15 older persons, a mail survey was conducted by sending to the 1,700 older persons along with a cover letter explaining the purpose of the study and informed consent procedures, two questionnaires (i.e., Clothing:
A Resource for Successful Aging? questionnaire and Personal Orientation Inventory (POI) with a computer scoring sheet), and a business reply envelope in late November, 2004. The above two questionnaires were used to measure the variables such as age identity, PCS, demographic characteristics (i.e., age, sex), and self-actualization.

The deliverable sample was 1,627 after subtracting out the subjects for whom an incorrect address was given, those that were returned as undeliverable by the U.S. Postal Service, and those no longer alive. Three weeks following the first mailing, a follow-up postcard was sent to all non-respondents. As a result, 195 older persons (12\% of the deliverable surveys) returned usable, completed questionnaires. The lower than expected response rate might be attributed to the conduct of the survey over a holiday season and a lengthy survey instrument. Length of the POI was somewhat of an issue; however, there was nothing that the researcher could do because this instrument was purchased and no changes could be made. The POI was administered to the survey subjects although the researcher was highly aware of this length issue.

\section{1) Proximity of Clothing to Self (PCS)}

The validated, 19-item PCS Scale for older persons (Lee \& Sontag, 2007) was used in this correlation analysis and included the three dimensions as clothing in relation to (1) self as structure - process, (2) self-esteem - evaluative and affective processes, and (3) body image and body cathexis. The 6-point Likert type response scale for measuring PCS was used: $1=$ Never or almost never true of me, $2=$ Usually not true of me, $3=$ Sometimes true of me, $4=$ Often true of me, $5=$ Usually true of me, and $6=$ Always or almost always true of me. High scores represent high PCS; low scores represent low PCS.

\section{2) Age Identity (AI)}

Cognitive Age Scale (Barak, 1987) was used to measure the concept of age identity, that is perceived age. Cognitive Age Scale is numerical, expressed in years, and measures subjectively-experienced age roles in terms of personal age dimensions related to functional areas of the self: psychological (Feel/Age), phys- 
ical (Look/Age), social/occupational (Do/Age), and intellectual (Interest/Age). Although multidimensional, Cognitive Age is a fairly simple survey scale to administer (Barak, 1987). Each respondent is asked to rate his/her self-perceived age status by specifying the absolute chronological age that most closely matches the way he/she feels, looks, acts, and thinks. The scoring of the scale used a decade-matching format (i.e., 20s, 30s, 40s, 50s, 60s, 70s, 80s, 90s).

\section{3) Self-Actualization (SA)}

The Personal Orientation Inventory (POI) is the only instrument published which claims to measure self-actualization (Shostrom, 1987). Consisting of 150 two-choice comparative value judgments, the test measures 12 elements of self-actualization. All items are to be scored twice: first, for the two basic scales of time-competence $\left(\mathrm{T}_{\mathrm{C}} ; 23\right.$ items) and inner-directedness (I; 127 items); and second, for the 10 subscales. The two major scales (i.e., $\mathrm{T}_{\mathrm{C}}$ and $\mathrm{I}$ ) use every item once, with a total of 150 items. Each item consists of two choices. The "incorrect" choices for the timecompetent scale are categorized under time-incompetent. The "incorrect" choices for the inner-directed scale are categorized under other-directed scale. The ten subscales are formed by using some of the 150 items more than once. If the scores on each of the 10 subscales are added together there is a total score of 219 , indicating that a considerable number of items are used more than once in the ten subscales. <Table 1> includes two major scales, 10 subscales of the POI, and definitions of each scale.

\section{Research Findings and Discussion}

Correlation analyses were conducted among the following three concepts: proximity of clothing to self, self-actualization, and age identity. Paired-sample ttests were also conducted to reveal significant differences between the means of these three variables within three different age categories. The results of this t-test and mean score of each variable could be found in Lee's study (2005).

\section{Proximity of Clothing to Self (PCS) and Self- Actualization (SA)}

According to clothing research conducted by Lee (2007), older persons who perceive clothing to be psychologically close to the self are less self-actualized than those for whom clothing is psychologically distant. Examining correlations among subscales of

Table 1. Self-Actualization measure: Components and definitions of the Personal Orientation Inventory (POI)

\begin{tabular}{|c|c|}
\hline SA Two Major Scales & What to Measure \\
\hline Time-Competence/Time-Incompetence $\left(\mathrm{T}_{\mathrm{C}} ; 23\right.$ items $)$ & the degree to which one is 'present' oriented \\
\hline Other/Inner Support (I; 127 items) & whether reactivity orientation is basically toward others or self \\
\hline SA 10 Subscales & What to Measure \\
\hline Self-Actualizing Value (SAV; 26 items) & affirmation of primary value of self-actualizing persons \\
\hline Existentiality (Ex; 32 items) & $\begin{array}{l}\text { ability to situationally or existentially react without rigid adherence to } \\
\text { principles }\end{array}$ \\
\hline Feeling Reactivity (Fr; 23 items) & sensitivity of responsiveness to one's own needs and feelings \\
\hline Spontaneity (S; 18 items) & freedom to react spontaneously or to be oneself \\
\hline Self-Regard (Sr; 16 items) & affirmation of self because of worth or strength \\
\hline Self-Acceptance (Sa; 26 items) & affirmation or acceptance of self in spite of weaknesses or deficiencies \\
\hline Nature of Man (Nc; 16 items) & $\begin{array}{l}\text { degree of the constructive view of the nature of man, masculinity, femi- } \\
\text { ninity }\end{array}$ \\
\hline Synergy (Sy; 9 items) & ability to be synergistic, to transcend dichotomies \\
\hline Acceptance of Aggression (A; 25 items) & $\begin{array}{l}\text { ability to accept one's natural aggressiveness as opposed to defensive- } \\
\text { ness, denial, and repression of aggression }\end{array}$ \\
\hline Capacity for Intimate Contact (C; 28 items) & $\begin{array}{l}\text { ability to develop contactful intimate relationships with other human } \\
\text { beings, unencumbered by expectations and obligations }\end{array}$ \\
\hline
\end{tabular}


each construct could provide clearer understanding of this negative path relationship of PCS to SA. <Table 2> reports correlations between the subscales of these two constructs. Only correlations significantly different from zero will be discussed.

For all respondents taken as a single group, overall SA was negatively correlated with the clothing in relation to self as structure - process (PCS Dim 1) and the clothing in relation to self-esteem - evaluative and affective processes (PCS Dim 2); however, no significant correlation was found between overall SA and the clothing in relation to body image and body cathexis (PCS Dim 3). Among the three age categories followed by the U.S. Bureau of the Census (2005) population age classification, overall SA only had significantly negative correlation with all three PCS subscales for the 75 to 84 years category.

For all respondents, the time-competent $\left(\mathrm{T}_{\mathrm{C}}\right)$ scale, one of the major scales in the SA, was negatively correlated with all three PCS subscales. For this $\mathrm{T}_{\mathrm{C}}$ scale, significantly negative correlations with all three
PCS subscales were found only for the 75 to 84 years group among the three age categories. No significant correlation was found for the age categories of 65 to 74 years, or 85 years and over. The other major scale on SA, the inner-directed scale, was only negatively correlated with the PCS Dimension 2 for all respondents. Just as with both overall SA and the $\mathrm{T}_{C}$ scale, negative correlations with the three PCS subscales were found for the 75 to 84 years group among the three age categories.

For the ten SA subscales and the three age categories, no significant correlation was found between the PCS subscales and the following SA subscales: selfactualizing value, self-regard, nature of man, synergy, acceptance of aggression, and feeling reactivity. The SA subscales, existentiality, spontaneity, and selfacceptance had significantly negative correlations with all three PCS subscales for the age category of 75 to 84 years. Self-acceptance also had significant correlations with PCS Dimensions 1 and Dimension 2 for those 85 years and over. The values of the correla-

Table 2. Correlations between the PCS subscales and Self-Actualization

\begin{tabular}{|c|c|c|c|c|}
\hline \multirow[b]{2}{*}{ Self-Actualization (SA) } & \multirow[b]{2}{*}{$\begin{array}{l}\text { Chronological } \\
\text { Age Category }\end{array}$} & \multicolumn{3}{|c|}{ Proximity of Clothing to Self (PCS) } \\
\hline & & $\begin{array}{c}\text { Dim } 1 \\
\text { Structure - Process }\end{array}$ & $\begin{array}{c}\text { Dim } 2 \\
\text { Self-Esteem }\end{array}$ & $\begin{array}{c}\text { Dim } 3 \\
\text { Body Image/Cathexis }\end{array}$ \\
\hline Overall SA & $\begin{array}{l}\text { All age groups } \\
65 \text { to } 74 \\
75 \text { to } 84 \\
85 \text { and over }\end{array}$ & $\begin{array}{l}-.166^{*} \\
.032 \\
-.299 * * \\
-.268\end{array}$ & $\begin{array}{l}-.283 * * \\
-.144 \\
-.384 * * \\
-.262\end{array}$ & $\begin{array}{l}-.139 \\
.089 \\
-.419 * * \\
-.021\end{array}$ \\
\hline Time-Competent & $\begin{array}{l}\text { All age groups } \\
65 \text { to } 74 \\
75 \text { to } 84 \\
85 \text { and over }\end{array}$ & $\begin{array}{l}-176^{*} \\
.016 \\
-.290^{*} \\
-.372\end{array}$ & $\begin{array}{l}-.190 * * \\
-.012 \\
-.347 * * \\
-.235\end{array}$ & $\begin{array}{l}-.152 * \\
.101 \\
-.470 * * \\
-.083\end{array}$ \\
\hline Inner-Directed & $\begin{array}{l}\text { All age groups } \\
65 \text { to } 74 \\
75 \text { to } 84 \\
85 \text { and over }\end{array}$ & $\begin{array}{l}-.139 \\
.032 \\
-.268 * \\
-.128\end{array}$ & $\begin{array}{l}-.274 * * \\
-.164 \\
-.352 * * \\
-.262\end{array}$ & $\begin{array}{l}-.117 \\
.078 \\
-.359 * * \\
-.021\end{array}$ \\
\hline Self-Actualizing Value & $\begin{array}{l}\text { All age groups } \\
65 \text { to } 74 \\
75 \text { to } 84 \\
85 \text { and over }\end{array}$ & $\begin{array}{r}.071 \\
.190 \\
-.041 \\
.090\end{array}$ & $\begin{array}{r}-.098 \\
-.080 \\
-.089 \\
.006\end{array}$ & $\begin{array}{r}.073 \\
.146 \\
-.029 \\
.159\end{array}$ \\
\hline Existentiality & $\begin{array}{l}\text { All age groups } \\
65 \text { to } 74 \\
75 \text { to } 84 \\
85 \text { and over }\end{array}$ & $\begin{array}{l}-.248 * * \\
-.027 \\
-.394 * * \\
-.305\end{array}$ & $\begin{array}{l}-.288 * * \\
-.094 \\
-.441 * * \\
-.262\end{array}$ & $\begin{array}{l}-.161 * \\
.092 \\
-.421 * * \\
-.024\end{array}$ \\
\hline Feeling Reactivity & $\begin{array}{l}\text { All age groups } \\
65 \text { to } 74 \\
75 \text { to } 84 \\
85 \text { and over }\end{array}$ & $\begin{array}{r}-.089 \\
.050 \\
-.144 \\
-.167\end{array}$ & $\begin{array}{l}-.157 * \\
-.070 \\
-.210 \\
-.041\end{array}$ & $\begin{array}{r}-.073 \\
.108 \\
-.219 \\
-.134\end{array}$ \\
\hline
\end{tabular}


Exploratory Correlation Analysis among Age Identity, Proximity of Clothing to Self, and Self-Actualization for Older Persons in the United States

Table 2. Continued

\begin{tabular}{|c|c|c|c|c|}
\hline \multirow[b]{2}{*}{ Self-Actualization (SA) } & \multirow{2}{*}{$\begin{array}{l}\text { Chronological } \\
\text { Age Category }\end{array}$} & \multicolumn{3}{|c|}{ Proximity of Clothing to Self (PCS) } \\
\hline & & $\begin{array}{c}\text { Dim } 1 \\
\text { Structure - Process }\end{array}$ & $\begin{array}{c}\text { Dim } 2 \\
\text { Self-Esteem }\end{array}$ & $\begin{array}{c}\text { Dim } 3 \\
\text { Body Image/Cathexis }\end{array}$ \\
\hline Spontaneity & $\begin{array}{l}\text { All age groups } \\
65 \text { to } 74 \\
75 \text { to } 84 \\
85 \text { and over }\end{array}$ & $\begin{array}{l}. .104 \\
.074 \\
-.226^{* *} \\
-.147\end{array}$ & $\begin{array}{l}-.181 * \\
-.099 \\
-.272 * \\
.006\end{array}$ & $\begin{array}{l}.035 \\
.151 \\
-.236^{*} \\
.016\end{array}$ \\
\hline Self-Regard & $\begin{array}{l}\text { All age groups } \\
65 \text { to } 74 \\
75 \text { to } 84 \\
85 \text { and over }\end{array}$ & $\begin{array}{l}.078 \\
.189 \\
.055 \\
.207\end{array}$ & $\begin{array}{r}-.113 \\
-.068 \\
-.080 \\
.099\end{array}$ & $\begin{array}{r}-.027 \\
.024 \\
-.083 \\
.273\end{array}$ \\
\hline Self-Acceptance & $\begin{array}{l}\text { All age groups } \\
65 \text { to } 74 \\
75 \text { to } 84 \\
85 \text { and over }\end{array}$ & $\begin{array}{l}.176^{*} \\
.035 \\
-.339 * * \\
-.489 * *\end{array}$ & $\begin{array}{l}-.251 * * \\
-.120 \\
-.371^{* *} \\
-.487 * *\end{array}$ & $\begin{array}{l}-.159 * \\
.034 \\
-.402 * * \\
-.265\end{array}$ \\
\hline $\begin{array}{l}\text { Nature of Man, } \\
\text { Constructive }\end{array}$ & $\begin{array}{l}\text { All age groups } \\
65 \text { to } 74 \\
75 \text { to } 84 \\
85 \text { and over }\end{array}$ & $\begin{array}{r}.001 \\
.008 \\
-.101 \\
.283\end{array}$ & $\begin{array}{r}-.040 \\
-.043 \\
-.085 \\
.147\end{array}$ & $\begin{array}{r}-.031 \\
.012 \\
-.164 \\
.145\end{array}$ \\
\hline Synergy & $\begin{array}{l}\text { All age groups } \\
65 \text { to } 74 \\
75 \text { to } 84 \\
85 \text { and over }\end{array}$ & $\begin{array}{l}-.007 \\
.153 \\
-.161 \\
-.025\end{array}$ & $\begin{array}{r}-.075 \\
.009 \\
-.189 \\
-.024\end{array}$ & $\begin{array}{r}-.031 \\
.104 \\
-.211 \\
.031\end{array}$ \\
\hline $\begin{array}{l}\text { Acceptance of } \\
\text { Aggression }\end{array}$ & $\begin{array}{l}\text { All age groups } \\
65 \text { to } 74 \\
75 \text { to } 84 \\
85 \text { and over }\end{array}$ & $\begin{array}{r}-.115 \\
.031 \\
-.127 \\
-.273\end{array}$ & $\begin{array}{l}-.192 * \\
-.100 \\
-.209 \\
-.055\end{array}$ & $\begin{array}{r}-.082 \\
.090 \\
-.195 \\
-.090\end{array}$ \\
\hline $\begin{array}{l}\text { Capacity for } \\
\text { Intimate Contact }\end{array}$ & $\begin{array}{l}\text { All age groups } \\
65 \text { to } 74 \\
75 \text { to } 84 \\
85 \text { and over }\end{array}$ & $\begin{array}{l}-.110 \\
-.007 \\
-.124 \\
-.152\end{array}$ & $\begin{array}{l}-.208^{* *} \\
-.140 \\
-.249 * \\
-.081\end{array}$ & $\begin{array}{r}-.066 \\
.060 \\
-.180 \\
.062\end{array}$ \\
\hline
\end{tabular}

*Correlation is significant at the 0.05 level (2-tailed)

**Correlation is significant at the 0.01 level (2-tailed)

tions are shown in 〈Table 2〉.

The existentiality measures one's flexibility in applying self-actualizing values to one's life. It measures one's ability to use good judgment in applying these general principles. Older persons who had higher scores on this subscale (i.e., higher flexibility in application of values), tended to be less psychologically close to clothing. Those who got low scores on the existentiality (i.e., holding values so rigidly that they may become compulsive or dogmatic), tend to be more psychologically close to clothing and may have a tendency to use clothing to improve their level of existentiality. Other environmental objects may serve a similar function.

A high score on the spontaneity indicates that older persons have ability to express feelings behaviorally or in spontaneous action. Older persons with a high score on the self-acceptance accept themselves in spite of their weaknesses or deficiencies. Older persons with high scores on these SA subscales may be more open toward change and to transition. These people might have a tendency to live their daily lives more holistically or spiritually rather than to attach themselves to a specific object. Conversely those with low scores on these subscales may use clothing to assist them in spontaneous action and self-acceptance. Further, this use of clothing may lead older persons to adapt to their transition periods more positively.

\section{Proximity of Clothing to Self (PCS) and Age Identity (AI)}

$<$ Table 3> shows correlations between overall AI 
Table 3. Correlations between the PCS subscales and each Indicator of age identity

\begin{tabular}{|c|c|c|c|}
\hline \multirow[b]{2}{*}{ Age Identity } & \multicolumn{3}{|c|}{ Proximity of Clothing to Self (PCS) } \\
\hline & $\begin{array}{c}\text { PCS Dim } 1 \\
\text { Structure - Process }\end{array}$ & $\begin{array}{l}\text { PCS Dim } 2 \\
\text { Self-Esteem }\end{array}$ & $\begin{array}{c}\text { PCS Dim } 3 \\
\text { Body Image/Cathexis }\end{array}$ \\
\hline $\begin{array}{l}\text { Overall AI } \\
\text { All age groups } \\
65 \text { to } 74 \\
75 \text { to } 84 \\
85 \text { and over }\end{array}$ & $\begin{array}{r}.120 \\
-.007 \\
.051 \\
-.177\end{array}$ & $\begin{array}{l}.164 * \\
.047 \\
.035 \\
-.198\end{array}$ & $\begin{array}{l}.055 \\
-.082 \\
-.026 \\
-.208\end{array}$ \\
\hline $\begin{array}{l}\text { I Feel } \\
\text { All age groups } \\
65 \text { to } 74 \\
75 \text { to } 84 \\
85 \text { and over }\end{array}$ & $\begin{array}{r}.133 \\
.067 \\
.075 \\
-.154\end{array}$ & $\begin{array}{l}.191 * * \\
.105 \\
.074 \\
-.013\end{array}$ & $\begin{array}{l}.051 \\
-.026 \\
-.022 \\
-.258\end{array}$ \\
\hline $\begin{array}{l}\text { I Look } \\
\text { All age groups } \\
65 \text { to } 74 \\
75 \text { to } 84 \\
85 \text { and over }\end{array}$ & $\begin{array}{c}.093 \\
.006 \\
.084 \\
-.375^{*} \\
\end{array}$ & $\begin{array}{r}.122 \\
.008 \\
.044 \\
-.291 \\
\end{array}$ & $\begin{array}{r}.076 \\
-.063 \\
.057 \\
-.156\end{array}$ \\
\hline $\begin{array}{l}\text { I Do } \\
\text { All age groups } \\
65 \text { to } 74 \\
75 \text { to } 84 \\
85 \text { and over }\end{array}$ & $\begin{array}{r}.065 \\
-.089 \\
-.016 \\
-.008\end{array}$ & $\begin{array}{r}.115 \\
-.019 \\
.029 \\
-.165\end{array}$ & $\begin{array}{r}.059 \\
-.100 \\
.020 \\
-.017\end{array}$ \\
\hline $\begin{array}{l}\text { My Interest } \\
\text { All age groups } \\
65 \text { to } 74 \\
75 \text { to } 84 \\
85 \text { and over }\end{array}$ & $\begin{array}{r}.108 \\
-.008 \\
.038 \\
-.013\end{array}$ & $\begin{array}{r}.115 \\
.041 \\
-.024 \\
-.113\end{array}$ & $\begin{array}{l}.005 \\
-.074 \\
-.132 \\
-.150\end{array}$ \\
\hline
\end{tabular}

*Correlation is significant at the 0.05 level (2-tailed)

**Correlation is significant at the 0.01 level (2-tailed)

and the three PCS subscales, and between the four indicators of $\mathrm{AI}$ and the PCS subscales. Overall AI was significantly correlated with PCS Dimension 2 for all respondents as a single group. No significant correlations were found on overall AI with either PCS Dimension 1 or PCS Dimension 3. Furthermore, no significant correlation was found between overall AI and all three PCS subscales for the three different age categories.

For the indicators of AI, the look item of $\mathrm{AI}$ and PCS Dimension 1 was negatively correlated for the age category of 85 years and over. It may be interpreted that older persons who reach 85 years and over use a human resource, clothing, to make themselves look younger than their chronological age and communicate their youthful self-image to others in social interaction. No significant correlation of the feel, do, and interest items of AI with the PCS subscales was found when respondents were subdivide by age categories. This examination discovers that older persons' age identity does not have much relationship with PCS except for the very old as explained above.

\section{Age Identity (AI) and Self-Actualization (SA)}

<Table 4> presents correlations of overall AI with overall SA, two major scales of the SA, and ten-subscales of the SA and of the four indicators of AI with overall SA, two major scales of the SA, and ten-subscales of the SA. Interestingly, a negative correlation between overall AI and overall SA was found for all respondents although Lee's (2007) path model showed almost no relationship of SA to AI. No significant correlation between overall SA and each of the four items of AI was found for the specific age categories, although for all respondents there was a significant, yet small negative correlation with three of the four indicators of AI (feel, do, and interest).

The look item had the least number of significant 
Exploratory Correlation Analysis among Age Identity, Proximity of Clothing to Self, and Self-Actualization for Older Persons in the United States

Table 4. Correlations between age identity and Self-Actualization

\begin{tabular}{|c|c|c|c|c|c|}
\hline \multirow{2}{*}{ Self-Actualization } & \multicolumn{5}{|c|}{ Age Identity } \\
\hline & Overall AI & I Feel & I Look & I Do & My Interest \\
\hline $\begin{array}{l}\text { Overall SA } \\
\text { All age groups } \\
65 \text { to } 74 \\
75 \text { to } 84 \\
85 \text { and over }\end{array}$ & $\begin{array}{l}-.166^{*} \\
-.067 \\
-.112 \\
.118\end{array}$ & $\begin{array}{l}-.148^{*} \\
-.081 \\
-.112 \\
.180\end{array}$ & $\begin{array}{r}-.099 \\
-.058 \\
-.004 \\
.321\end{array}$ & $\begin{array}{l}-.145^{*} \\
-.017 \\
-.171 \\
.147\end{array}$ & $\begin{array}{l}-.155^{*} \\
-.055 \\
-.067 \\
-.278\end{array}$ \\
\hline $\begin{array}{l}\text { Time-Competent } \\
\text { All age groups } \\
65 \text { to } 74 \\
75 \text { to } 84 \\
85 \text { and over }\end{array}$ & $\begin{array}{r}-.088 \\
-.041 \\
-.068 \\
.094\end{array}$ & $\begin{array}{r}-.068 \\
.015 \\
-.089 \\
.109\end{array}$ & $\begin{array}{r}-.036 \\
-.003 \\
-.007 \\
.259\end{array}$ & $\begin{array}{l}-.161 * \\
-.057 \\
-.190 \\
-.151\end{array}$ & $\begin{array}{r}-.018 \\
.002 \\
.061 \\
.097\end{array}$ \\
\hline $\begin{array}{l}\text { Inner-Directed } \\
\text { All age groups } \\
65 \text { to } 74 \\
75 \text { to } 84 \\
85 \text { and over }\end{array}$ & $\begin{array}{l}-.172 * \\
-.074 \\
-.111 \\
.049\end{array}$ & $\begin{array}{l}-.157 * \\
-.097 \\
-.106 \\
.124\end{array}$ & $\begin{array}{r}-.111 \\
-.066 \\
-.003 \\
.220\end{array}$ & $\begin{array}{r}-.129 \\
-.006 \\
-.147 \\
.162\end{array}$ & $\begin{array}{l}-.174 * \\
-.064 \\
-.094 \\
-.341\end{array}$ \\
\hline $\begin{array}{l}\text { Self-Actualizing Value } \\
\text { All age groups } \\
65 \text { to } 74 \\
75 \text { to } 84 \\
85 \text { and over }\end{array}$ & $\begin{array}{l}-.197 * * \\
-.140 \\
-.267 * \\
.023\end{array}$ & $\begin{array}{l}-.159^{*} \\
-.081 \\
-.252^{*} \\
.043\end{array}$ & $\begin{array}{l}-.097 \\
-.056 \\
-.099 \\
.061\end{array}$ & $\begin{array}{l}-.178^{*} \\
-.149 \\
-.262^{*} \\
.156\end{array}$ & $\begin{array}{l}-.213^{* *} \\
-.148 \\
-.253^{*} \\
-.195\end{array}$ \\
\hline $\begin{array}{l}\text { Existentiality } \\
\text { All age groups } \\
65 \text { to } 74 \\
75 \text { to } 84 \\
85 \text { and over }\end{array}$ & $\begin{array}{l}-.160 * \\
-.210^{*} \\
.039 \\
.226\end{array}$ & $\begin{array}{l}-.168 * \\
-.209 * \\
.014 \\
.052\end{array}$ & $\begin{array}{l}-.128 \\
-.240^{*} \\
.098 \\
.416^{*}\end{array}$ & $\begin{array}{r}-.100 \\
-.065 \\
.008 \\
.226\end{array}$ & $\begin{array}{r}-.137 \\
-.171 \\
.034 \\
-.015\end{array}$ \\
\hline $\begin{array}{l}\text { Feeling Reactivity } \\
\text { All age groups } \\
65 \text { to } 74 \\
75 \text { to } 84 \\
85 \text { and over }\end{array}$ & $\begin{array}{l}-.216 * * \\
-.088 \\
-.268 * \\
.024\end{array}$ & $\begin{array}{l}-.165^{*} \\
-.089 \\
-.221 \\
.186\end{array}$ & $\begin{array}{l}-.155^{*} \\
-.048 \\
-.131 \\
-.027\end{array}$ & $\begin{array}{l}-.188^{* *} \\
-.042 \\
-.253^{*} \\
-.016\end{array}$ & $\begin{array}{l}-.212^{* * *} \\
-.094 \\
-.275^{*} \\
-.091\end{array}$ \\
\hline $\begin{array}{l}\text { Spontaneity } \\
\text { All age groups } \\
65 \text { to } 74 \\
75 \text { to } 84 \\
85 \text { and over }\end{array}$ & $\begin{array}{l}-.223^{*} \\
-.104 \\
-.222 \\
-.175\end{array}$ & $\begin{array}{l}-.168^{*} \\
-.106 \\
-.177 \\
.061\end{array}$ & $\begin{array}{l}-.127 \\
-.041 \\
-.042 \\
-.066\end{array}$ & $\begin{array}{l}-.190 * * \\
-.041 \\
-.247 * \\
-.118\end{array}$ & $\begin{array}{l}-.253^{* *} \\
-.133 \\
-.243^{*} \\
-.354\end{array}$ \\
\hline $\begin{array}{l}\text { Self-Regard } \\
\text { All age groups } \\
65 \text { to } 74 \\
75 \text { to } 84 \\
85 \text { and over }\end{array}$ & $\begin{array}{l}-.239 * * \\
-.102 \\
-.219 \\
-.097\end{array}$ & $\begin{array}{r}-.139 \\
.025 \\
-.218 \\
.132\end{array}$ & $\begin{array}{r}-.119 \\
-.035 \\
-.047 \\
.111\end{array}$ & $\begin{array}{l}-.274 * * \\
-.161 \\
-.278 * \\
-.167\end{array}$ & $\begin{array}{l}-.257 * * \\
-.158 \\
-.162 \\
-.303\end{array}$ \\
\hline $\begin{array}{l}\text { Self-Acceptance } \\
\text { All age groups } \\
65 \text { to } 74 \\
75 \text { to } 84 \\
85 \text { and over }\end{array}$ & $\begin{array}{l}.076 \\
.094 \\
.132 \\
.083\end{array}$ & $\begin{array}{l}.031 \\
.020 \\
.083 \\
.081\end{array}$ & $\begin{array}{l}.100 \\
.049 \\
.157 \\
.367\end{array}$ & $\begin{array}{l}.070 \\
.114 \\
.056 \\
.105\end{array}$ & $\begin{array}{r}.067 \\
.117 \\
.165 \\
-.258\end{array}$ \\
\hline $\begin{array}{l}\text { Nature of Man, Constructive } \\
\text { All age groups } \\
65 \text { to } 74 \\
75 \text { to } 84 \\
85 \text { and over }\end{array}$ & $\begin{array}{l}-.107 \\
-.026 \\
-.339 * \\
.206\end{array}$ & $\begin{array}{c}-.096 \\
.013 \\
-.314^{*} \\
.062\end{array}$ & $\begin{array}{l}-.107 \\
-.073 \\
-.226^{*} \\
.093\end{array}$ & $\begin{array}{l}-.084 \\
-.048 \\
-.364 * \\
.358\end{array}$ & $\begin{array}{r}-.076 \\
.011 \\
-.209 \\
.034\end{array}$ \\
\hline
\end{tabular}

- 1905 - 
Table 4. Continued

\begin{tabular}{|c|c|c|c|c|c|}
\hline \multirow{2}{*}{ Self-Actualization } & \multicolumn{5}{|c|}{ Age Identity } \\
\hline & Overall AI & I Feel & I Look & I Do & My Interest \\
\hline $\begin{array}{l}\text { Synergy } \\
\text { All age groups } \\
65 \text { to } 74 \\
75 \text { to } 84 \\
85 \text { and over }\end{array}$ & $\begin{array}{r}-.072 \\
-.074 \\
-.101 \\
.150\end{array}$ & $\begin{array}{r}-.035 \\
.018 \\
-.128 \\
.150\end{array}$ & $\begin{array}{l}-.043 \\
-.151 \\
-.033 \\
.416^{*}\end{array}$ & $\begin{array}{l}-.044 \\
-.002 \\
-.111 \\
.147\end{array}$ & $\begin{array}{l}-.120 \\
-.142 \\
-.053 \\
-.234\end{array}$ \\
\hline $\begin{array}{l}\text { Acceptance of Aggression } \\
\text { All age groups } \\
65 \text { to } 74 \\
75 \text { to } 84 \\
85 \text { and over }\end{array}$ & $\begin{array}{l}-.216^{* *} \\
-.122 \\
-.123 \\
.011\end{array}$ & $\begin{array}{l}-.176^{*} \\
-.130 \\
-.103 \\
.192\end{array}$ & $\begin{array}{r}-.131 \\
-.055 \\
.001 \\
.108\end{array}$ & $\begin{array}{l}-.174^{*} \\
-.068 \\
-.138 \\
.131\end{array}$ & $\begin{array}{l}-.235^{* * *} \\
-.121 \\
-.146 \\
-.390 *\end{array}$ \\
\hline $\begin{array}{l}\text { Capacity for Intimate Contact } \\
\text { All age groups } \\
65 \text { to } 74 \\
75 \text { to } 84 \\
85 \text { and over }\end{array}$ & $\begin{array}{l}-.139 \\
-.048 \\
-.081 \\
-.040\end{array}$ & $\begin{array}{r}-.091 \\
-.040 \\
-.071 \\
.156\end{array}$ & $\begin{array}{r}-.091 \\
-.100 \\
.026 \\
.188\end{array}$ & $\begin{array}{r}-.089 \\
.079 \\
-.072 \\
-.111\end{array}$ & $\begin{array}{l}-.195 * * \\
-.117 \\
-.125 \\
-.298\end{array}$ \\
\hline
\end{tabular}

*Correlation is significant at the 0.05 level (2-tailed)

**Correlation is significant at the 0.01 level (2-tailed)

correlations with the 10 SA subscales among the four AI items. It is possible to say that older persons who are self-fulfilled in their daily lives may perceive themselves younger than their chronological age. Older persons who are more self-actualized may have less tendency to emphasize how they look or are viewed by others. These people may be less sensitive to their physical changes and accept these changes positively through the aging process. They may have a greater tendency to incorporate their interests that they've had through their previous life experiences.

Shostrom (1987) argued that a self-actualizing person was primarily time-competent and thus appeared to live more fully in the here-and-now. Such a person was able to tie the past and the future to the present in meaningful continuity; appeared to be less burdened by guilt, regrets, and resentments from the past than was the non-self-actualizing person, and aspirations were tied in a meaningful way to present working goals. Based on this theoretical ground, this researcher wanted to observe whether older persons who were highly self-actualized might have a similar age identity to their chronological age and then this similar age identity might contribute to their satisfaction with life.

For the subscales of the SA, negative correlations of overall AI on six subscales [i.e., Self-Actualizing Value (SAV), Existentiality (Ex), Feeling reactivity (Fr),
Spontaneity (S), Self-regard (Sr), and Acceptance of aggression (A)] were found for all respondents. Among these SA subscales, the Feeling reactivity (Fr) was negatively correlated with all four AI indicators. The SAV, S, and A subscales had negative correlations with the feel, do, and interest items of AI. The $\mathrm{Sr}$ subscale had negative correlations with the do and interest items of AI and the Ex subscale was negatively correlated with only one indicator, the feel item, of AI. The do item of AI was most frequently correlated among these six SA subscales for the age category of 75 to 84 years, followed by the interest item, the feel item, and the look item. These negative correlations suggest that older persons who are selffulfilled in their daily lives for these specific SA subscales might perceive themselves younger than their chronological age.

\section{Conclusions and Implications for the Future}

This research focused on exploring correlations among Proximity of Clothing to Self (PCS), Age Identity (AI), and Self-Actualization (SA). Correlation analysis among subscales of each construct supported the negative path effect of PCS on SA. Correlation analysis of the two major SA scales and overall SA were significantly, negatively correlated 
with all three PCS subscales only for the 75 to 84 year group. These findings bring awareness that older persons within this age category were different from those in the age category of 65 to 74 years and 85 years and over. Older persons in this age range may be undergoing psychological transitions.

For the ten SA subscales across the three age categories, extistentiality, spontaneity, and self-acceptance had significantly negative correlations with all three PCS subscales for the age category of 75 to 84 years. Correlation analyses between each indicator of AI and the PCS subscales revealed that the look item of AI and PCS Dimension 1 was negatively correlated for those 85 years and over. It may be interpreted that older persons who reach 85 years and over use a human resource, clothing, to make themselves look younger than their chronological age and communicate their youthful self-image to others in social interaction. This examination discovered that older persons' age identity does not have much relationship with PCS except for the very old.

From the correlation analyses of AI with SA, a negative correlation between overall AI and overall SA was found for all respondents before subdividing by the three age categories. No significant correlation was found for the time-competent scale of the SA with the overall $\mathrm{AI}$ and three $\mathrm{AI}$ indicators (i.e., feel, look and interest items). Through exploring the correlations among these two constructs, no positive correlations were found. Therefore, it is possible to say that older persons who are highly self-actualized perceive themselves younger than their chronological age. In other words, older persons who have younger age identity have a tendency to be more selfactualized than those who have older age identity.

The instrument POI (to measure SA) has been used many times in previous studies for clinical therapy purposes by examining the level of each subscale. However, little previous research has tried to use this instrument as a construct to test directional relationships and correlations with other clothing variables. Further effort is needed to use this instrument as a measure of self-actualization in the area of clothing and behavioral sciences. One option would be using the 10 SA subscales as an indicator of SelfActualization (SA) instead of using the overall SA score. For different target subjects, specific SA subscales may perform differently; thus a researcher can select the best performing SA subscales when he or she conducts new research. Further in-depth research is necessary to explore the relationship of these SA subscales with various clothing variables such as clothing interest, clothing importance, clothing involvement, or clothing satisfaction. <Table 5> summarizes the SA subscales that have negative correlations with $\mathrm{AI}$ and PCS for older persons to provide a reference for future research.

Several limitations were related to a mail survey procedure and survey instruments. The POI instrument was lengthy for older persons to answer. It took around 30 to 60 minutes to answers 150 questions. These might lead to tiredness while filling in ques-

Table 5. Summary of Self-Actualization (POI) subscales that have relationship with age identity and PCS

\begin{tabular}{l|c|c}
\hline \multirow{2}{*}{ SA subscales } & \multicolumn{2}{|c}{ Negative Correlation with the SA Subscale } \\
\cline { 2 - 3 } & $\mathrm{PCS}$ & Age Identity \\
\hline Self-Actualizing Value (SAV) & & $\mathrm{X}[\mathrm{x}]$ \\
Existentiality (Ex) & $\mathrm{X}[\mathrm{x}]$ & $\mathrm{X}[\mathrm{x}]$ \\
Feeling Reactivity (Fr) & $\mathrm{X}[\mathrm{x}]$ & $\mathrm{X}[\mathrm{x}]$ \\
Spontaneity (S) & & $\mathrm{X}[\mathrm{x}]$ \\
Self-Regard (Sr) & $\mathrm{X}[\mathrm{x}]$ & $\mathrm{X}[\mathrm{x}]$ \\
Self-Acceptance (Sa) & & {$[\mathrm{x}]$} \\
Nature of Man (N) & $\mathrm{X}$ & $\mathrm{x}]$ \\
Synergy (Sy) & $\mathrm{X}[\mathrm{x}]$ & $\mathrm{X}[\mathrm{x}]$ \\
Acceptance of Aggression (A) & $\mathrm{X}$ \\
Capacity for Intimate Contact (Ca) & & \\
\hline
\end{tabular}

" $\mathrm{X}$ " indicates negative correlation for all respondents; $[\mathrm{x}]$ indicates negative correlation for the different age categories such as 65 to 74 years, 75 to 84 years, and 85 years and over. 
tionnaires and could cause them to give up responding to the survey and account in part at least for the low response rate.

This close-ended mail survey design is limited in terms of in-depth interpretation of the responses from older persons. A different research design might reveal interesting facts or explanations that the survey design could not achieve. Longitudinal design can reveal effects that cannot be caught in cross sectional study. For instance, by comparing older persons' reactions to and perceptions of the human-built environment (i.e., clothing) and beliefs, values, and needs as they go through the process of aging, a researcher may have a clear and in-depth understanding of their selfsystem process when interacting with various environments. Performing on-site interviews several times during this suggested longitudinal study also will add more thorough understanding of their life changes. Further, it could provide more insight about how older persons adapt to their transition periods from young-old (65 to 74 years) to middle old (75 to 84 years) to old-old (85 years and over).

This study explored social/psychological aspects of older persons' lives using psychological variables (i.e., PCS, age identity, self-actualization). Further research should be conducted to explore relationships among PCS, different levels of human needs (i.e., safety, selfesteem, belonging) and psychological well-being for this older group. In addition, another study with a similar age group of this study needs to be conducted to obtain more generalizable research results and further advance statistical analyses (i.e., path analysis) also need to be completed to understand direct or indirect causal relationships among these variables. In terms of an empirical approach, the benefit of this research lies in the possibilities for older persons to use clothing as a resource to maintain or improve their daily activities or lives.

\section{References}

Barak, B. (1987). Cognitive age: A new multidimentional approach to measuring age identity. International Journal of Aging and Human Development, 25(2), 109-128.

Baum, S. K., \& Boxley, R. L. (1983). Age identification in the elderly. The Gerontologist, 23, 532-537.

Chowdhary, U. (1988). Self-esteem, age identification, and media exposure of the elderly and their relationship to fashionability. Clothing and Textiles Research Journal, 7(1), 23-30.

Chowdhary, U. (2000). Correlates of apparel significance among older men and women. Journal of Consumer Studies and Home Economics, 24(3), 150-159.

Combs, A. W., \& Snygg, D. (1959). Individual behavior: A perceptual approach to behavior. New York: Harper and Brothers.

Creekmore, A. M. (1974). Clothing related to body satisfaction and perceived peer self (Research Report No. 239). East Lansing, MI: Michigan Agricultural Experiment Station.

Lee, J. (1997). Proximity of clothing to self: Its relationship to self-perception, clothing deprivation and gender among adolescents. Unpublished doctoral dissertation, Michigan State University, East Lansing.

Lee, Y. A. (2005). Older persons' successful aging: Relationships among proximity of clothing to self, age identity, and self-actualization. Unpublished doctoral dissertation, Michigan State University, East Lansing.

Lee, Y. A. (2007). A conceptual model for studying the impact of clothing, self-actualization, and psychographic variables on successful aging. The Gerontologist: $60^{\text {th }}$ annual scientific meeting "The era of global aging: Challenges \& opportunities," 47(1), 710-711.

Lee, Y. A., \& Sontag, M. S. (2007). Validation of the proximity of clothing to self scale for older persons. Journal of Korean Society of Clothing and Textiles, 31(6), 848858.

Linn, M. W., \& Hunter, K. (1979). Perception of age in the elderly. Journal of Gerontology, 34, 46-52.

Lynn, M. L. (1990). Proximity of clothing to self: Implications for the elderly consumer. Unpublished master's thesis. University of Illinois at Urbana Champaign, Urbana.

Maslow, A. H. (1970). Motivation and personality. New York: Harper \& Row, Publishers.

Pasnak, M. F. D., \& Ayres, R. W. (1969). Clothing attitudes and personality characteristics of fashion innovators. Journal of Home Economics, 61(9), 698-702.

Pederson, E. L. (1989). Clothing: A basic human need? Home Economics FORUM, 3(2), 18-19.

Rowe, J. W., \& Kahn, R. L. (1998). Successful aging. New York: A Dell Trade Paperback.

Salant, P., \& Dillman, D. A. (1994). How to conduct your own survey. New York: Wiley.

Shostrom, E. L. (1987). Personal Orientation Inventory (POI) manual. San Diego, CA: Educational and Industrial Testing Service.

Sontag, M. S. (1978). Clothing as an indicator of perceived quality of life. Doctoral dissertation, Michigan State 
University, East Lansing.

Sontag, M. S., \& Lee, J. N. (2004). Proximity of clothing to self scale. Clothing and Textiles Research Journal, 22(4), 161-177.

Sontag, M. S., \& Schlater, J. D. (1982). Proximity of clothing to self: Evolution of a concept. Clothing and Textiles Research Journal, 1, 1-8.

U.S. Bureau of the Census. (2001). The 65 years and over population: 2000. Washington, DC: U.S. Government
Printing Office.

U.S. Bureau of the Census. (2005). Current population reports, 65+ in the United States: 2005 (No. P23-209). Washington, DC: U.S. Government Printing Office.

Vreeman, A. L. (1985) Apparel purchase behavior: An investigation of apparel as a high involvement product. Unpublished master's thesis, University of Illinois at Urbana Champaign, Urbana.

\section{요 약}

Lee(2007)의 연구에서 노년들의 의복에 대한 자아 근접성은 그들의 자아실현에 직접적인 긍정적 영향 을 미친다고 가설하였으나 가설과는 반대의 부정적 영향을 미치며 나이 정체성이 자아실현에 직접적인 영 향을 주지 않는다는 결과를 얻었다. 이 세 변수들 사이의 연관성은 이전의 연구들에서 많이 다루어지지 않 았기에 Lee(2007)의 연구결과의 타당성을 입증하기위한 부가 연구가 필요하여졌다. 이 논문은 Lee(2007) 의 연구결과를 심도 있게 이해하기 위하여 노년층의 의복에 대한 자아 근접성, 나이 정체성, 자아실현 사 이의 상호 연관성을 분석하였다. 세 변수와 노인들의 나이와 성별을 묻는 설문지를 미국 전역 50 개 주의 1,700 명의 노인들에게 배포하여 195 명으로부터 응답을 받았다. 미국 인구 통계청의 연령 구분 체계에 따 라 설문지에 응답한 노인들을 세 분류의 나이(65세와 74세 사이, 75세와 84세 사이, 85세와 그 이상)로 구 분지어 연구결과를 분석하였다. 이 연구는 노인들의 나이 정체성은 나이 85 세 이상의 노인들을 제외하고 는 의복의 자아 근접성과 그다지 상호 연관성이 많지 않음을 입증 하였다. 이 결과는 자아실현을 달성하 지 못한 노인들은 의복을 자아실현을 위한 하나의 도구로 사용 할 수 있다고도 해석되어 질 수 있다. 세 변수들의 상호 연관성 분석은 75 세와 84 세 사이의 노인들은 나머지 두 연령층의 노인들 $(65$ 세와 74 세 사 이, 85 세와 그 이상)과 상당히 다름을 입증하였다. 이는 75 세와 84 세 사이의 노인들이 다른 나이층의 노 년들 보다 더 많은 심리적 과도기를 거치고 있음일 수도 있다. 이 연구결과를 통하여 노년층이라 구분지 어지는 연령대가 높아져 간다는 것이 입증되어 졌으며 과거 50세를 넘긴 이들이 자신들을 노년층이라 생 각 하였었다면 이제는 노인들 자신들도 그들을 더 이상 노인으로 구분 짖는 기준선이 적어도 미국에서는 불명확해 지고 있음이 보인다. 자아실현 변수는 의류학 분야에서는 이제까지 상당히 추상적으로만 사용 되어져 왔고 측정도구로는 많이 상용화 되어 있지 않은 실정이다. 이 글에서 제시하는 자아실현의 세부 변수들을 토대로 의복과의 상호 관련 연구들이 앞으로 더 체계적으로 이루어져야 할 것이다. 